\title{
The Impact of Financial Flexibility on Enterprise Risk-Taking
}

\author{
Yunli Liu* \\ School of Economics and Management \\ Jiangxi University of Science and Technology \\ Ganzhou, 341000,China \\ 2576048506@qq.com
}

Correspondent Author: Yunli Liu

\author{
Yuan Chang \\ School of Economics and Management \\ Jiangxi University of Science and Technology \\ Ganzhou, 341000,China \\ 182529061@qq.com
}

\begin{abstract}
Economic globalization has made corporate risks complex and diverse. In recent years, the international economic environment and China's policy changes have prompted people to increase their risk awareness. Enterprise risk-taking is the fundamental driving force for economic growth and is vital to the survival and development of enterprises. Therefore, based on the theory of resource dependence, this paper takes the A-share listed non-financial enterprises in 2014-2018 as a sample and establishes a fixed-effect model to study the impact of financial flexibility on the enterprises risk-taking. The research finds that financial flexibility can significantly promote enterprise risktaking, in non-state-owned enterprises and agents. In enterprises with low conflicts, financial flexibility plays a more stronger role in promoting corporate risk-taking. The research in this paper not only enriches the relevant literature on financial flexibility and enterprise risk commitment, but also contributes to the financial resource reserve and risk commitment decision of the enterprise.
\end{abstract}

Keywords-financial flexibility; Enterprise risk-taking; property right; agency cost

\section{INTRODUCTION}

Under the new normal economic situation in China, economic growth is changing from high-speed growth to highquality growth, and the state has issued a series of policies (supply-side reform, six-stable policy, etc.). As the main body of social economy, the survival and development of enterprises play an important role in the realization of high-quality economic development in our country. In 2018, the impact of Sino-US trade war on the market economy has increased the risk of business operations. Changes in policies and the international economic environment have reminded companies to increase risk awareness and increase corporate risk-taking. As the fundamental driving force for long-term sustainable economic growth, enterprise risk-taking is very important for corporate value enhancement and overall social economic growth [1].[2].

After the outbreak of the financial crisis, corporate risktaking has entered the field of scholars and has become a new topic in academic research. The research on the influencing factors of enterprise risk-taking in the literature has focused on the following aspects: macroeconomic policy, corporate governance (equity structure, board structure, management incentives, etc.) and management characteristics (age, psychology, gender, etc.)[3]-[4]. Enterprise risk-taking means a large amount of resource consumption, and has a strong dependence on resources. Without resource support, enterprise risk-taking activities are difficult to maintain. Taking into account the resource dependence, scholars began to study the ability of the external resources of the enterprise to study the impact of CEO or corporate social capital (financial, political, overseas and other social capital) and social responsibility on corporate risk-taking[5]-[2]. In addition to obtaining resources from outside, companies can also obtain resources from within. Although external resources can enable enterprises to obtain greater benefits (economies of scale, reputation, etc.), in the case of unstable external environment or macroeconomic optimism, it is difficult for enterprises to obtain resources from outside, at this time internal resources for enterprise survival and development is extremely important.

The financial flexibility mainly comes from the enterprise's cash holding and residual debt-raising ability [6], reflecting the ability of external resources and internal resources to acquire, and has greater flexibility in resource acquisition. The research on the economic consequences of financial flexibility mainly focuses on enterprise value, investment efficiency, investment level, capital structure, etc. Most of them regard enterprise risktaking as an intermediate variable, and rarely study financial flexibility and enterprise risk-taking separately. Then considering both internal and external resources, according to the theory of resource dependence, will financial flexibility have an impact on enterprise risk-taking? Is there any difference between state-owned enterprises and non-stateowned enterprises? Does the inherent agency problem affect the relationship between them?

Therefore, this paper takes the A-share listed non-financial enterprises in 2014-2018 as a sample to test the relationship between financial flexibility and corporate risk-taking. Combining the particularity of ownership in China and the inherent agency problems of enterprises, this paper explores the role of property rights and agency costs in the relationship between them. This is not only helpful to enrich the relevant literature on risk-taking, but also helpful for enterprises to make resource reserve decisions, control and utilize enterprise risk-taking, enhance enterprise value and achieve long-term sustainable development. 


\section{LITERATURE REVIEW}

\section{A. Financial Flexibility Literature Review}

Financial flexibility was considered to be the ability of enterprises to adapt and prevent environmental uncertainty in the early days. After the outbreak of the financial crisis, they began to realize that financial flexibility has the property of "utilization" of unexpected events. It is believed that financial flexibility not only reflects the ability of enterprises to obtain and utilize financial resources, but also provides resources for enterprises to cope with environmental changes[7]. In general, financial flexibility is the result of resource reserve decisions in order to deal with emergencies, which reflects the risk awareness and coping ability of enterprises[8]. Financial flexibility comes from cash holding, residual debt raising ability and equity financing ability of enterprises. Because of the imperfect capital market in China, equity financing can only be obtained by listed companies, and the financing cost is high. Therefore, financial flexibility mainly comes from cash holding and residual debt raising ability[9]. The research on the economic consequences of financial flexibility mainly focuses on the level of investment, investment efficiency and enterprise value. Denis and Sibilkov[10]study the financing constraints and cash holding value of listed companies in the United States, and find that financing constraints will limit the investment of enterprises. In order to maintain or increase investment, enterprises will increase cash holdings in order to maintain financial flexibility. Hongbing and Yujun[9]found that in enterprises with financing constraints, the stronger the role of financial flexibility in promoting the investment level of enterprises, the higher the investment efficiency. Yao and Feifei[11] found that the more fierce the market competition, the greater the uncertainty of the external environment of the enterprise, the more motivation to maintain financial flexibility and promote the value of the enterprise. Haiying, Qingfang, and Jie[12]also proved this by his research on A-share listed companies in China, especially in the case of high uncertainty in the external environment, the stronger the effect of holding financial flexibility on the value of enterprises.

\section{B. Risk-taking Literature Review}

Corporate risk-taking refers to the analysis and choice of investment projects that can bring expected returns and future cash flows, but are full of uncertainty[13], which reflects the willingness or commitment of enterprises to pay a high price to obtain high returns[14]. After the outbreak of financial crisis, corporate risk-taking has been paid more and more attention, and scholars have carried out research on it one after another. The research on the influencing factors of risk taking mainly focuses on macroeconomic, enterprise characteristics, corporate governance, management characteristics (age, gender, psychology, etc.). Mclean and Zhao[15]think that macroeconomic changes will affect the attitude of enterprises to risk. They found that when the recession and tight credit policy will make enterprises have negative emotions, risk aversion, choose conservative investment policies. The level of enterprise risk taking is low. Habib and Hasan[16]found that when the enterprise is in the period of introduction and recession, the risk behavior is more and the level of risk taking is higher. They also found that when the mood of institutional investors was high and the capital market was irrational, the cost of external financing was lower, and managers were more inclined to choose risky investments. Studies by Faccio, Marchica and Mura[17] and Peltom ä ki et al.[18] showed that women CEO and older CEO had lower risk taking levels, which made enterprises tend to choose projects with lower risk Qi and Xianghui[19] believe that equity incentive can narrow the interest difference between management and shareholders, help executives overcome risk aversion behavior, and then improve corporate risk taking. Some scholars have studied the impact of CEO or corporate social responsibility and corporate social capital on corporate risk-taking. They believe that CEO or corporate social capital and the performance of corporate social responsibility are conducive to the acquisition of external resources, thereby enhancing corporate risktaking[2].[5].

In summary, it is not difficult to find that risk taking is mainly affected by enterprise resource acquisition ability and management risk preference, and there are few literatures that combine enterprise internal and external resource acquisition ability to consider enterprise risk-taking. Therefore, this paper selects A-share listed non-financial enterprises from 2014 to 2018 as the research object to test the impact of financial flexibility on corporate risk-taking.

\section{THEORETICAL ANALYSIS AND HYPOTHESIS PROPOSED}

\section{A. Financial flexibility and Enterprise risk-taking}

Enterprise risk-taking is a resource-consuming activity, which reflects the resources that enterprises are willing to invest in the face of highly uncertain projects. It has a strong dependence on enterprise resources. Therefore, the amount, quality and acquisition ability of enterprise resources will affect enterprise risk-taking behavior[5]. Financial flexibility reflects the ability of enterprises to obtain financial resources and restructure financial activities at low cost[20]. The reason why enterprises reserve financial flexibility is to cope with uncertainty in the future, so that enterprises can avoid financial constraints and bankruptcy dilemma when facing adverse external factors (such as macro-policy adjustment, economic depression); when investment opportunities arise, they can quickly finance funds in a low-cost way and seize opportunities in time[21]. Enterprise management decision-making is in the hands of management, so enterprise risk-taking is affected not only by the ability of enterprises to acquire resources, but also by the willingness of management to take risks, which has been proved in the research of scholars[21].[17]. their research indicates that management characteristics (such as age, gender, personality, etc.) are significantly correlated with corporate risk taking. The change of management's environment will affect their psychological deviation, and then influence the decisionmaking of enterprises[22]. When facing high-risk investment projects with investment value, the resource acquisition ability of enterprises may affect the psychological bias of management, make them adjust their perception of project risk, thereby reducing management's risk aversion and improving corporate risk-taking. Therefore, hypothesis 1 is proposed as follows: 
Hypothesis 1: financial flexibility is positively related to enterprise risk-taking.

\section{B. The role of agency costs in financial flexibility and corporate risk taking}

According to agency theory, the inconsistency of interests between managers and shareholders makes managers make decisions that deviate from the goal of maximizing shareholders' wealth. In addition, the high uncertainty brought by the risk-taking behavior of enterprises makes the management face such risks as salary, position and reputation, which results in that the management often has more risk aversion motivation than the shareholders[2]. Financial flexibility mainly comes from internal cash and residual liability ability. While providing resources for enterprise risktaking, it may also increase management's private interest motivation and make management abandon high-risk and highreturn investment projects, especially those risk-averse management. One reason is that excessive cash holdings give management greater control over resources, which makes management more inclined to abuse resources; the other is that too low debt weakens the governance role of debt, reduces external supervision of management, and reduces its operating pressure[7]. In enterprises with low agency cost, the agency conflict of enterprises is small, the interests between management and shareholders tend to be more consistent, and the management may be more willing to take risk-taking behavior, thereby improving the risk-taking of enterprises. Therefore, hypothesis 2 is proposed as follows:

Hypothesis 2: In enterprises with low agency costs, financial flexibility plays a stronger role in promoting risktaking.

\section{The role of property rights in financial flexibility and corporate risk taking}

The particularity of ownership in our country may makes the willingness of management to bear risks and the ability of enterprises to obtain resources are different. On the one hand, government intervention reduces the decision-making power of state-owned enterprise management and enhances the risk aversion emotion of management; on the other hand, the administrative mechanism of state-owned enterprise compensation and the limitation of executive decision-making income make moral hazard and opportunity more serious, and management is more inclined to risk aversion when facing high-risk decision-making 13]. Studies have shown that the risk-taking of state-owned enterprises is significantly lower than that of non-state-owned enterprises [23]-[24]. In terms of enterprise resource acquisition ability, on the one hand, stateowned enterprises have distorted management objectives and bear too much policy burden, which makes it easier to get government relief and resources to improve their management [23]. On the other hand, since state-owned enterprises are agents of the state or government, banks or financial institutions are more willing to lend to them, and state-owned enterprises have lower financing constraints [25]. In the light of these two considerations, it is proposed to assume 3:
Hypothesis 3: In the state-owned enterprises, the financial flexibility has a little effect on the risk-taking.

\section{RESEARCH DESIGN}

\section{A. Variable Definition}

\section{1) Dependent variable: risk taking}

Corporate risk taking means the consumption of a lot of resources, which will bring fluctuations in corporate performance. At present, the volatility of earnings or stock returns is commonly used at home and abroad to measure risk taking. In this paper, the method of Boubakri, Cosset and Saffar[24] and peng, Lili and Changhong[26] is used for reference, and the volatility of asset return rate adjusted by industry (subdivided manufacturing industry) is adopted to measure enterprise risk taking in accordance with the industry classification of China securities regulatory commission in 2012. The calculation formula is as follows:

$$
\begin{gathered}
\operatorname{Adj} R O A_{\mathrm{ijt}}=R O A_{\mathrm{ijt}}-\frac{1}{n_{j \mathrm{t}}} \sum_{\mathrm{k}=1}^{n_{j \mathrm{t}}} R O A_{\mathrm{ijt}} \\
R T_{1}=\sqrt{\frac{1}{T-1} \sum_{\mathrm{i}=1}^{T}\left(\operatorname{Adj} R O A_{\mathrm{ijt}}-\frac{1}{T} \sum_{\mathrm{i}=1}^{T} \operatorname{Adj} R O A_{\mathrm{ijt}}\right)^{2}}, T=5
\end{gathered}
$$

Where, $R O A_{i j t}$ is the asset return rate of enterprise $\mathrm{i}$ in industry $\mathrm{j}$ at the end of $\mathrm{t}$ year, $A d j R O A_{\mathrm{ijt}}$ is the asset return rate adjusted by the annual average of the industry.

\section{2) Independent variable: financial flexibility}

Financial flexibility reflects the ability of an enterprise to obtain internal and external resources, which is mainly composed of cash flexibility and liability flexibility. Therefore, this paper USES the method of Jianqing and Huaijin[28] to measure financial flexibility, and defines financial flexibility $=$ cash flexibility + liability flexibility. Where cash flexibility = Max $\{0$, enterprise cash holding level - industry average cash holding level $\}$, liability flexibility $=\operatorname{Max}\{0$, enterprise debt level - industry average debt level\}.

3)Moderating variables: property right nature and agency cost

According to the previous analysis, different property rights and agency conflicts will affect the allocation of enterprise resources. Based on this, the property rights and agency costs are selected as moderating variables in this paper. Generally, the lower the management expense ratio, the smaller the agency cost and the smaller the agency conflict. Therefore, this paper takes management expense ratio as the proxy variable of agency cost and whether the enterprise belongs to state-owned enterprise as the proxy variable of property right.

\section{4)Control variables}

Enterprise risk-taking is affected by other factors besides financial flexibility. By referring to relevant studies on other factors affecting risk taking and referring to the studies of Boubakri, Cosset and Saffar[24], Zhenshan and Dalin[27] and Lijuan and Dunli[2], the control variables are selected from the aspects of enterprise characteristics and corporate governance. Enterprise characteristic variables are market value to book ratio, growth, tangible assets ratio, sales gross profit rate and enterprise size, corporate governance variables are the largest shareholder's shareholding ratio, degree of equity balance and 
institutional investors' shareholding. The variable definitions in this paper are shown in TABLE I:

TABLE I. VARIABLE DEFINITION

\begin{tabular}{|c|c|c|c|}
\hline $\begin{array}{l}\text { Variable } \\
\text { Types }\end{array}$ & $\begin{array}{l}\text { Variable } \\
\text { Name }\end{array}$ & $\begin{array}{l}\text { Variable } \\
\text { Symbol }\end{array}$ & $\begin{array}{l}\text { Variable Definition and } \\
\text { Description }\end{array}$ \\
\hline $\begin{array}{l}\text { Dependent } \\
\text { Variable }\end{array}$ & Risk-taking & RT & $\begin{array}{l}\text { Standard deviation of } \\
\text { industry-adjusted ROA } \\
\text { for five consecutive years } \\
\text { is shown in formula (1) }\end{array}$ \\
\hline $\begin{array}{l}\text { Independent } \\
\text { Variable }\end{array}$ & $\begin{array}{l}\text { Financial } \\
\text { Flexibility }\end{array}$ & $\mathrm{FF}$ & $\begin{array}{l}\max \{0 \text {, Corporate cash } \\
\text { holding level - Industry } \\
\text { average cash holding } \\
\text { Level }\}+\max \{0, \\
\text { Industry average debt } \\
\text { level-enterprise average } \\
\text { debt level }\}\end{array}$ \\
\hline \multirow{2}{*}{$\begin{array}{l}\text { Moderating } \\
\text { Variable }\end{array}$} & $\begin{array}{l}\text { Agency } \\
\text { Cost }\end{array}$ & $\mathrm{AC}$ & $\begin{array}{l}\text { The administrative } \\
\text { expense ratio is used as } \\
\text { the substitute variable of } \\
\text { agency cost }\end{array}$ \\
\hline & $\begin{array}{l}\text { Property } \\
\text { rights }\end{array}$ & SOE & $\begin{array}{l}\text { If the enterprise is state- } \\
\text { owned, the SOE is } 1 \text {, and } \\
\text { vice versa }\end{array}$ \\
\hline \multirow{8}{*}{$\begin{array}{l}\text { Control } \\
\text { Variable }\end{array}$} & $\begin{array}{l}\text { Market-to- } \\
\text { book ratio }\end{array}$ & МТВ & $\begin{array}{l}\text { The market value/book } \\
\text { value ratio of a } \\
\text { company's stock }\end{array}$ \\
\hline & $\begin{array}{l}\text { Shareholdi } \\
\text { ng ratio of } \\
\text { the largest } \\
\text { shareholder }\end{array}$ & Topshare & $\begin{array}{l}\text { The number of shares } \\
\text { held by the largest } \\
\text { shareholder / Total } \\
\text { equity } \times 100 \%\end{array}$ \\
\hline & $\begin{array}{l}\text { the equity } \\
\text { balance } \\
\text { degree }\end{array}$ & $\mathrm{CS}$ & $\begin{array}{l}\text { The sum of the } \\
\text { shareholding ratio of the } \\
\text { second to the tenth } \\
\text { largest shareholder/the } \\
\text { largest shareholder }\end{array}$ \\
\hline & $\begin{array}{l}\text { Institutiona } \\
1 \quad \text { investor } \\
\text { shareholdin } \\
\mathrm{g} \text { ratio }\end{array}$ & Inst & $\begin{array}{l}\text { Total holdings by } \\
\text { institutional investors / } \\
\text { Total equity } \times 100 \%\end{array}$ \\
\hline & Growth & Growth & $\begin{array}{l}\text { ( The market value of } \\
\text { the equity }+ \text { Book value } \\
\text { of liabilities ) / total } \\
\text { assets } \times 100 \%\end{array}$ \\
\hline & $\begin{array}{l}\text { Proportion } \\
\text { of tangible } \\
\text { assets }\end{array}$ & Tang & $\begin{array}{l}\text { Net fixed assets / total } \\
\text { assets } \times 100 \%\end{array}$ \\
\hline & $\begin{array}{l}\text { Gross } \\
\text { profit } \\
\text { margin }\end{array}$ & GPR & $\begin{array}{l}\text { (Main business income } \\
- \text { Main business cost) / } \\
\text { Main business income } \\
\times 100 \%\end{array}$ \\
\hline & $\begin{array}{l}\text { Enterprise } \\
\text { size }\end{array}$ & Size & $\begin{array}{l}\text { The natural logarithm of } \\
\text { the total assets at the end } \\
\text { of the period }\end{array}$ \\
\hline
\end{tabular}

\section{B. Model Construction}

Establish the following model based on the assumptions: Model 1:

$$
R \mathrm{~T}_{\mathrm{i}_{1} \mathrm{t}}=\beta_{0}+\beta_{1} F F_{\mathrm{i}_{i} \mathrm{t}}+\beta_{2} C V_{\mathrm{i}_{\mathrm{s}} \mathrm{t}}+\sum \text { firm }+\sum \text { year }+\varepsilon_{\mathrm{i}_{1,} \mathrm{t}}
$$

Model t2:

$$
R \mathrm{~T}_{\mathrm{i}, \mathrm{t}}=\beta_{0}+\beta_{1} F F_{\mathrm{i}_{\mathrm{j}} \mathrm{t}}+\beta_{2} A C_{\mathrm{i}, \mathrm{t}} \times F F_{\mathrm{i}, \mathrm{t}}+\beta_{2} A C_{\mathrm{i}, \mathrm{t}}+\beta_{4} C \mathrm{CV}_{\mathrm{i}, \mathrm{t}}+\sum_{\text {firm }}+\sum_{\text {year }}+\varepsilon_{\mathrm{i}, \mathrm{t}}
$$

Model 1 is used to test hypothesis 1 . On the basis of model 1, the interaction term $\mathrm{AC} \times \mathrm{FF}$ is introduced to establish model

2 for verifying hypothesis 2. Property rights are dummy variables, which may bring collinearity problems. In order to avoid one of the influences, model 1 is run in groups according to property rights to test hypothesis 3 . The model framework is shown in Figure 1.

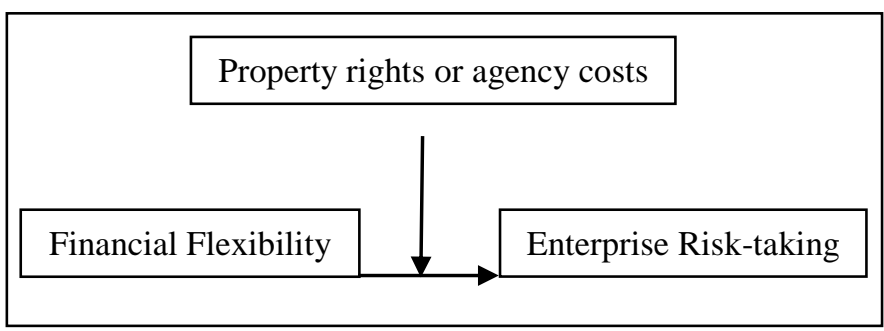

Fig. 1. Model Framework

\section{METHODOLOGY}

\section{A. Sample Selection and Data Sources}

This paper selects the A-share listed company from 2014 to 2018 as the initial sample. Since the risk-taking agent variable is the fluctuation of the rate of return, the variable data is extended to 2010. In order to ensure the reliability of the empirical results, the data is selected according to the following principles in order to ensure the reliability of the empirical results: (1) the enterprises that have been specially treated are eliminated; (2) enterprises with missing key variables are eliminated; (3) Enterprises with net assets less than 0 are excluded; (4) enterprises with less than 5 enterprises in the industry are removed. And finally, 10805 observation values are obtained. In order to avoid the influence of extreme values, this paper carries out the up-and-down $1 \%$ reduction of all continuous variables. Data processing uses Excel and Stata.15.

\section{B. Selection of Analysis Mmethod}

In this paper, hausman test is carried out to determine whether the data is suitable for the fixed effect model or the random effect model. The results show that chi2(16)=188.72 and $\mathrm{P}$ value is 0.0000 , indicating that the data is suitable for the fixed effect model. Therefore, this paper chooses the fixed effect model for data analysis. In order to avoid the influence of the existence of heteroscedasticity and autocorrelation on the empirical results, this paper adopts white method to adjust the standard error of the model.

\section{DATA ANALYSIS AND RESULT}

\section{A. Descriptive Statistics}

It can be seen TABLE II. from that the minimum, average and maximum values of RT are $0.49,4.02$ and 18.14, respectively. It can be seen that enterprise risk taking is skewed to the right, and the overall risk taking level is relatively small. The minimum value, mean value and maximum value of $\mathrm{FF}$ are $0,11.49$ and 63.57 , respectively, and the standard deviation is 14.25. It can be seen that the financial flexibility of enterprises presents right-biased distribution, and there is a big difference among enterprises. The average SOE is 0.4 , 
meaning that $40 \%$ of the sample is state-owned. The standard deviation of control variables Topshare, Inst, Tang, Growth and GPR is above 14. Compared with other variables, the volatility is relatively large, indicating that there are large differences in corporate governance and characteristics among enterprises. The Size standard deviation is 1.27 , and the Size of each enterprise is between 20 and 27, indicating that no largescale expansion or contraction occurs during the observation period.

TABLE II. VARIABLES DESCRIBE THE STATISTICAL RESULTS

\begin{tabular}{|c|c|c|c|c|c|}
\hline variable & $\mathbf{N}$ & mean & sd & min & max \\
\hline RT & 10805 & 4.02 & 3.61 & 0.49 & 18.14 \\
\hline FF & 10805 & 11.49 & 14.25 & 0 & 63.57 \\
\hline SOE & 10805 & 0.4 & 0.49 & 0 & 1 \\
\hline AC & 10805 & 10.02 & 8.5 & 0.83 & 54.47 \\
\hline MTB & 10805 & 3.7 & 3.11 & 0.65 & 19.38 \\
\hline Topshare & 10805 & 33.57 & 14.6 & 8.45 & 73.82 \\
\hline CS & 10805 & 0.92 & 0.78 & 0.05 & 3.82 \\
\hline Inst & 10805 & 40.88 & 23.19 & 0.65 & 88.05 \\
\hline Tang & 10805 & 21.9 & 16.71 & 0.19 & 70.81 \\
\hline Growth & 10805 & 15.32 & 30.17 & -30.6 & 185.45 \\
\hline GPR & 10805 & 28.22 & 16.99 & -0.03 & 81.1 \\
\hline Size & 10805 & 22.44 & 1.27 & 20.07 & 26.24 \\
\hline
\end{tabular}

\section{B. Correlation test}

TABLE III reports the correlation between the variables. The correlation coefficient between FF and RT is 0.111 ( $\mathrm{p}<$ 0.01 ), that is, the financial flexibility is significantly positively correlated with the risk commitment. Hypothesis 1 is initially verified. The correlation coefficient between SOE and RT was -0.059 ( $p<0.01)$, and the correlation coefficient between AC and RT was $0.18(\mathrm{p}<0.01)$. That is, property rights and agency costs were significantly correlated with corporate risk-taking. The correlation coefficient between FF and SOE was -0.16 ( $\mathrm{p}<$ 0.01 ), and the correlation coefficient between FF and AC was 0.212 ( $\mathrm{p}<0.01$ ). In summary, the nature of property rights and agency costs may play a role between financial flexibility and corporate risk taking. The correlation coefficients between other variables are around 0.5 and below, and there is no serious collinearity between the variables.

\begin{tabular}{c|c|c|c|c|c|c}
\hline Variables & $\mathbf{1}$ & $\mathbf{2}$ & $\mathbf{3}$ & $\mathbf{4}$ & $\mathbf{5}$ & $\mathbf{6}$ \\
\hline 1.RT & 1 & & & & & \\
\hline 2.FF & $0.111^{* * *}$ & 1 & & & & \\
\hline 6.Topshare & -0.004 & $-0.016^{*}$ & $0.282^{* * *}$ & $-0.171^{* * *}$ & $-0.091^{* * *}$ & 1 \\
\hline 7.CS & $0.030^{* * *}$ & $0.037^{* * *}$ & $-0.285^{* * *}$ & $0.105^{* * *}$ & $0.059^{* * *}$ & $-0.711^{* * *}$ \\
\hline 8.Inst & $-0.063^{* * *}$ & $-0.099^{* * *}$ & $0.429^{* * *}$ & $-0.202^{* * *}$ & $-0.133^{* * *}$ & $0.506^{* * *}$ \\
\hline 9.Tang & 0 & $-0.140^{* * *}$ & $0.174^{* * *}$ & $-0.110^{* * *}$ & $-0.112^{* * *}$ & $0.092^{* * *}$ \\
\hline 10.Growth & 0.013 & 0.006 & $-0.169^{* * *}$ & 0.009 & $0.102^{* * *}$ & $-0.077^{* * *}$ \\
\hline 11.GPR & $0.068^{* * *}$ & $0.222^{* * *}$ & $-0.195^{* * *}$ & $0.379^{* * *}$ & $0.156^{* * *}$ & $-0.039^{* * *}$ \\
\hline 12.Size & $-0.155^{* * *}$ & $-0.33^{* * *}$ & $0.326^{* * *}$ & $-0.389^{* * *}$ & $-0.469^{* * *}$ & $0.260^{* * *}$ \\
\hline \multicolumn{7}{r}{$* 0.10, * * \mathrm{p}<0.05,{ }^{* * *} \mathrm{p}<0.01(2-$ tailed $)$} \\
\hline
\end{tabular}

Connect the above TABLE IV

\begin{tabular}{|c|c|c|c|c|c|c|}
\hline Variables & 7 & 8 & 9 & 10 & 11 & 12 \\
\hline \multicolumn{7}{|l|}{ 1.RT } \\
\hline \multicolumn{7}{|l|}{ 2.FF } \\
\hline \multicolumn{7}{|l|}{$3 . \mathrm{SOE}$} \\
\hline \multicolumn{7}{|l|}{ 4.AC } \\
\hline \multicolumn{7}{|l|}{ 5.MTB } \\
\hline \multicolumn{7}{|l|}{ 6.Topshare } \\
\hline 7.CS & 1 & & & & & \\
\hline 8.Inst & $-0.255^{* * *}$ & 1 & & & & \\
\hline 9.Tang & $-0.084^{* * *}$ & $0.113^{* * *}$ & 1.000 & & & \\
\hline 10.Growth & $0.167^{* * * *}$ & $-0.071^{* * *}$ & $-0.201^{* * * *}$ & 1 & & \\
\hline 11.GPR & $0.106^{* * * *}$ & $-0.063^{* * *}$ & $-0.147^{* * *}$ & $0.147^{* * *}$ & 1 & \\
\hline 12.Size & $-0.086^{* * *}$ & $0.427^{* * * *}$ & $0.049^{* * * *}$ & $0.048^{* * *}$ & $-0.138^{* * * *}$ & 1 \\
\hline
\end{tabular}

\section{Result}

\section{1)Regression analysis} taking

a) the impact of financial flexibility on enterprise risk-

TABLE V reports the empirical results of the relationship between financial flexibility and risk taking. The results show that the correlation coefficient of FF and RT is 0.0217 and significant at the level of $1 \%$, that is, financial flexibility is significantly positively correlated with risk taking. Hypothesis 1 is verified.

TABLE III. PEARSON CORRELATION TEST

\begin{tabular}{c|c|c|c|c|c|c}
\hline Variables & $\mathbf{1}$ & $\mathbf{2}$ & $\mathbf{3}$ & $\mathbf{4}$ & $\mathbf{5}$ & $\mathbf{6}$ \\
\hline 1.RT & 1 & & & & & \\
\hline $2 . \mathrm{FF}$ & $0.111^{* * *}$ & 1 & & & & \\
\hline $3 . \mathrm{SOE}$ & $-0.059^{* * *}$ & $-0.106^{* * *}$ & 1 & & & \\
\hline $4 . \mathrm{AC}$ & $0.180^{* * *}$ & $0.212^{* * *}$ & $-0.164^{* * *}$ & 1 & & \\
\hline $5 . \mathrm{MTB}$ & $0.215^{* * *}$ & $0.094^{* * *}$ & $-0.185^{* * *}$ & $0.360^{* * *}$ & 1 & \\
\hline
\end{tabular}


TABLE IV. FINANCIAL FLEXIBILITY AND RISK TAKING

\begin{tabular}{cc}
\hline & $\mathrm{RT}$ \\
\hline FF & $0.0217^{* * * *}$ \\
MTB & $(0.0063)$ \\
& $0.0647^{* *}$ \\
Topshare & $(0.0261)$ \\
& $\left(0.0182^{* * *}\right.$ \\
CS & $0.5705^{* * *}$ \\
& $(0.1614)$ \\
Inst & $-0.0145^{* * *}$ \\
& $(0.0045)$ \\
Tang & $-0.0189^{* *}$ \\
& $(0.0074)$ \\
Growth & $-0.0040^{* * *}$ \\
& $(0.0013)$ \\
GPR & $0.0217^{* * *}$ \\
& $(0.0077)$ \\
Size & -0.2846 \\
& $(0.1889)$ \\
cons & $9.2188^{* *}$ \\
& $(4.2721)$ \\
\hline Year & YES \\
Firm & YES \\
$N$ & 10805 \\
F & $19.8310^{* * * *}$ \\
$\mathrm{R}^{2} \_\mathrm{a}$ & 0.5602 \\
\hline parentheses $* \mathrm{p}<0.10, * * \mathrm{p}<0.05, * * * \mathrm{p}<0.01$ \\
& \\
&
\end{tabular}

b) The moderation role of agency cost between financial flexibility and risk taking

TABLE VI reports the test results of hypothesis 2 . When the interaction term $\mathrm{AC} \times \mathrm{FF}$ is not put away (the results are shown in the first column), the model is adjusted with $\mathrm{R}$ square 0.5613 and $F$ value is 18.6204 ( $p<0.01$ ). After adding the interaction term of $\mathrm{AC} \times \mathrm{FF}$ (the results are shown in the second column), the model is adjusted by $\mathrm{R}$ square of 0.5618 , greater than 0.05618 , and $F$ value is 18.2329 ( $p<0.01$ ), which indicates that agency cost plays a significant moderating role between financial flexibility and enterprise risk taking. In the first column, the correlation coefficient between FF and RT is 0.0210 , which is significant at $1 \%$ level. In the second column, the correlation coefficient between FF and RT is 0.0314, greater than 0.021 and significant at $1 \%$ level. The correlation coefficient between $\mathrm{AC} \times \mathrm{FF}$ and $\mathrm{RT}$ was -0.0008 , which was significant at $10 \%$ level. It can be seen that the correlation between FF and RT and the correlation between $\mathrm{AC} \times \mathrm{FF}$ and RT are significant, but the direction is opposite, which indicates that in enterprises with low agency costs, financial flexibility plays a stronger role in promoting risk taking.

TABLE V. MODERATING EFFECT OF AGENCY COS

\begin{tabular}{ccc} 
& $(1)$ & $(2)$ \\
\hline FF & $0.0210^{* * *}$ & $0.0314^{* * *}$ \\
& $(0.0063)$ & $(0.0089)$ \\
AC & $0.0304^{* * *}$ & $0.0435^{* * *}$ \\
& $(0.0106)$ & $(0.0121)$ \\
ACXFF & & $-0.0008^{*}$ \\
& & $(0.0005)$ \\
MTB & $0.0585^{* * *}$ & $0.0577^{* *}$ \\
& $(0.0254)$ & $(0.0253)$ \\
Topshare & $0.0387^{* * *}$ & $0.0389^{* * *}$ \\
& $(0.0111)$ & $(0.0111)$ \\
CS & $0.5775^{* * *}$ & $0.5788^{* * *}$ \\
& $(0.1620)$ & $(0.1615)$ \\
Inst & $-0.0144^{* * *}$ & $-0.0143^{* * *}$ \\
\hline
\end{tabular}

\begin{tabular}{ccc}
\hline & $(1)$ & $(2)$ \\
\hline FF & $0.0210^{* * * *}$ & $0.0314^{* * *}$ \\
& $(0.0063)$ & $(0.0089)$ \\
Tang & $(0.0045)$ & $(0.0045)$ \\
& $-0.0188^{* *}$ & $-0.0186^{* *}$ \\
Growth & $(0.0074)$ & $(0.0074)$ \\
& $-0.0039^{* * *}$ & $-0.0040^{* * *}$ \\
GPR & $(0.0013)$ & $(0.0013)$ \\
& $0.0199^{* * *}$ & $0.0202^{* *}$ \\
Size & $(0.0079)$ & $(0.0079)$ \\
& -0.2278 & -0.2176 \\
& $(0.1897)$ & $(0.1896)$ \\
cons & $(0.1527)$ & $(0.1522)$ \\
& $7.6979^{*}$ & $7.3143^{*}$ \\
Year & $(4.3008)$ & $(4.2980)$ \\
Firm & YES & YES \\
$N$ & YES & YES \\
F & 10805 & 10805 \\
$\mathrm{R}^{2} \_\mathrm{a}$ & $18.6204^{* * *}$ & $18.2329^{* * *}$ \\
\hline rd errors in parentheses & $* .5613$ & 0.5618 \\
\hline
\end{tabular}

c) The moderation role of the nature of property rights in financial flexibility and risk takingon.

TABLE VII is the result of grouping test of model 1, which is used to verify the mediation effect of property right nature. As can be seen from the table, in the $\mathrm{SOE}=1$ group, the correlation coefficient between FF and RT was 0.0106, which failed the significance test. In the $\mathrm{SOE}=0$ group, the correlation coefficient between FF and RT was 0.0278, greater than 0.0106 , and significant at $1 \%$ level, passing the significance test. It is not difficult to find that in non-state-owned enterprises, the influence of FF on RT is significantly higher than that of non-state-owned enterprises $(0.0278>0.0106)$. So hypothesis 3 is validated.

TABLE VI. MODERATING EFFECT OF PROPERTY RIGHTS

\begin{tabular}{lcc}
\hline & $\mathrm{SOE}=1$ & $\mathrm{SOE}=0$ \\
\hline FF & 0.0106 & $0.0278^{* * *}$ \\
MTB & $(0.0099)$ & $(0.0077)$ \\
& $0.0820^{* * *}$ & $0.0802^{* *}$ \\
Topshare & $(0.0410)$ & $(0.0339)$ \\
& $0.0334^{* * *}$ & $0.0503^{* * *}$ \\
CS & $(0.0136)$ & $(0.0170)$ \\
& $0.5675^{* *}$ & $0.6210^{* * *}$ \\
Inst & $(0.2388)$ & $(0.2055)$ \\
& $-0.0173^{* *}$ & $-0.0137^{* *}$ \\
Tang & $(0.0071)$ & $(0.0057)$ \\
& -0.0149 & $-0.0223^{* *}$ \\
Growth & $(0.0093)$ & $(0.0110)$ \\
& -0.0012 & $-0.0040^{* * *}$ \\
GPR & $(0.0024)$ & $(0.0015)$ \\
& $0.0289^{* * *}$ & $0.0179^{*}$ \\
Size & $(0.0088)$ & $(0.0109)$ \\
& $-0.5427^{* *}$ & -0.1519 \\
cons & $(0.2478)$ & $(0.2598)$ \\
& $15.3486^{* * *}$ & 5.7691 \\
Year & $(5.4404)$ & $(5.8931)$ \\
Firm & YES & YES \\
$N$ & YES & YES \\
F & 4370 & 6435 \\
$\mathrm{R}^{2} \_\mathrm{a}$ & $7.4677^{* * *}$ & $15.9567^{* * *}$ \\
\hline errors in parentheses & $* .6194$ & 0.5310 \\
\hline & & $0.05, * * * \mathrm{p}<0.01$ \\
& &
\end{tabular}

2)Robustness test 
In order to avoid the contingency of the results, the robustness of the research results is tested in this paper. The method of replacing variables is used to test. That is, to replace the proxy variables of risk assumption, the industry adjusted return on assets within 5 years is used to measure the risk burden, and the regression analysis is carried out again. The robustness test results are shown in TABLE VIII-IX in the appendix.

The results show that in model $1, \mathrm{FF}$ is significantly positively correlated with RT (correlation coefficient is 0.0521 , $\mathrm{p}<0.001$ ). In model 2 , after adding the interaction term of $\mathrm{AC}$ $\times$ FF, FF is significantly positively correlated with RT (correlation coefficient is $0.0503, \mathrm{p}<0.001$ ). There was a significant negative correlation between $\mathrm{AC} \times \mathrm{FF}$ and $\mathrm{RT}$ (correlation coefficient was-0.002, $\mathrm{p}<0.10$ ). In the group regression of model 1 , when $\mathrm{SOE}=1$ was used, FF was positively correlated with RT (correlation coefficient was 0.0291 ), but did not pass the significant test. When $\mathrm{SOE}=0, \mathrm{FF}$ was significantly positively correlated with RT (correlation coefficient was $0.0656, \mathrm{p}<0.001$ ). It could be seen that the results were consistent with the original results. This shows that the results of the study are robust.

\section{CONCLUSION AND DISCUSSION}

According to the above analysis, it is found that the level of enterprise risk taking is low and the gap of financial flexibility among enterprises is large. In the empirical analysis, the results of the data analysis are consistent with the theoretical expectations. In the face of investment decisions, financial flexibility can significantly promote enterprises to make risktaking decisions and dare to take risks. Agency cost and property right nature play an important role in regulating the relationship between financial flexibility and enterprise risktaking. In non-state-owned enterprises, the role of financial flexibility in promoting enterprise risk will be enhanced. At the same time, the enterprise agency cost is low, that is to say, in the enterprise with small agency conflict, the promoting effect of financial flexibility on enterprise risk taking will also be enhanced.

As the driving force of enterprise and even social development, financial flexibility improves the convenience of resources for enterprise risk-taking behavior, so how to make full use of financial flexibility to play its role? How to make use of the moderating function of agency cost and property right nature, how to give full play to the promoting effect of financial flexibility on enterprise risk-taking? This paper holds that when enterprises make financial flexible reserve decisions, they should pay attention to two points: Firstly, we should pay attention to the agency conflict of enterprises, narrow the gap of interests between management and shareholders, and then reduce the risk aversion mood of management, so that management can take risks bravely; secondly, we should pay attention to government intervention in enterprises, so as to avoid the excessive interference of the government, which makes the financial flexibility difficult to play its expected role.

\section{A. Contribution and Significance}

The contribution of this study has two points. Firstly, it enriches the existing literature. Most of the existing studies focus on macroeconomic policies, management characteristics and corporate governance, but less on the perspective of enterprise resource acquisition capability. Based on the resource dependence theory, and considered the internal and external resource acquisition capabilities of enterprises comprehensively. The paper studies the influencing factors of enterprise risk-taking. Secondly, the study finds that the nature of property rights and agency costs play a moderating role between financial flexibility and risk-taking, which not only helps enterprises to make financial flexibility reserve decisions, but also helps enterprises to make risk-taking behavior decisions, and promotes healthy development of enterprises.

\section{B. Research limitations and future research}

Financial flexibility comes from internal and external sources, and the influence of different resource sources on enterprise risk taking may be different. However, this study does not consider the internal and external resource acquisition capabilities of enterprises separately, and ignores the structure of financial flexibility. In the future, we can start from the structure of internal and external resources to study the impact of financial flexibility structure on enterprise risk taking, so as to reserve better financial flexibility for enterprise risk taking behavior.

\section{ACKNOWLEDGMENT}

We are very grateful to the leaders and teachers of the English Writing Summer Camp of Jiangxi University of Technology, especially the writing guide of Dr. Ebenezer Atta Mills and Dr. Isaac Kofi Mensah.

\section{REFERENCES}

[1] Acemoglu D , Zilibotti F . Was Prometheus Unbound by Chance? Risk, Diversification, and Growth. Journal of Political Economy, 1997, 105(4):709-751

[2] Zhao Lijuan, Zhang Dunli. CEO Social Capital and Enterprise Risk Taking: Based on the Theoretical Perspective of Principal-Agent and Resource Acquisition. Journal of Shanxi University of Finance and Economics, 2019, 41(02): 80-92.

[3] Li Bingcheng, Xiao Han, Pei Peiting. Literature Review and Prospect of Enterprise Risk Taking Research. Statistics and Decision, 2017(13) 171-175.

[4] Wang Jinghua, Mao Ning. Review and Prospect of Enterprise Risk Taking Research. Foreign Economics and Management, 2015, 37(12): 44-58

[5] Wang Jianling, Li Yuting, Wu Wei. Corporate Social Responsibility and Risk Taking: Based on the Perspective of Resource Dependence Theory. Forecast, 2019, 38 (03): 45-51

[6] Li Yan, An Ye, Li Mofu. The Impact of Financial Flexibility on NonEfficiency Investment of Enterprises-Based on the Research of Shanghai and Shenzhen A-Share Non-financial Listed Companies. Tax and Economy, 2015(05): 47-54.

[7] Zeng Aimin, Zhang Chun, Zhu Zhaohui. Recent Developments in Western Financial Flexibility Theory. Business Economics and Management, 2014(10): 43-54. 
[8] Luo Dongliang, Liu Fan, Jiao Yumeng. Vertical Team Characteristics, Financial Flexibility and Enterprise Value Creation of Executive Teams. Journal of Nanjing Audit University, 2019, 16(04): 31-41.

[9] Chen Hongbing, Lian Yujun. The Impact of Financial Resilience on Enterprise Investment Level and Investment Efficiency. Economic Management, 2013, 35(10): 109-118.

[10] Denis D J and Sibilkov V.Financial constraints, investment, and the value of cash holdings. Review of Financial Studies, 2010, 23 (1) :247269.

[11] Li Yao, Cong Feifei. The Choice of Capital Structure of Private Enterprises under Industrial Competition-Taking Yuning Yunshang as an Example. Accounting Research, 2015(04): 47-54+96.

[12] Pan Haiying, Hu Qingfang, Fang Jie. Financial crisis, financial flexibility and corporate value- based on the perspective of financing constraints. Industrial Technology \& Economy, 2019, 38(04): 116-125.

[13] Yu Minggui, Li Wengui, Pan Hongbo. Privatization, Property Rights Protection and Enterprise Risk Taking. Economic Research, 2013, 48(09): 112-124.

[14] Johan Wiklund,Dean Shepherd. Entrepreneurial orientation and small business performance: a configurational approach. Journal of Business Venturing,2005,20(1).

[15] Mclean R D , Zhao M . The Business Cycle, Investor Sentiment, and Costly External Finance. The Journal of Finance, 2014, 69(3):13771409.

[16] Habib A, Hasan M M , Cahan S . Firm life cycle, corporate risk-taking and investor sentiment. Accounting \& Finance, 2015, doi:10.1111/acfi.12141

[17] Faccio M , Marchica M T , Mura R . CEO gender, corporate risk-taking, and the efficiency of capital allocation[J]. Journal of Corporate Finance, 2016, 39 (8): 193-209.

[18] Peltomäki, Jarkko, Swidler S, Vähämaa, Sami. Age, Gender, and RiskTaking: Evidence from the S\&P 1500 Executives and Firm Riskiness. Social Science Electronic Publishing, 2015.

[19] Zhu Qi, Chen Xianghui, Hou Ya. Executive Equity Incentives Affect Corporate Risk-taking Behavior: Evidence from Microdata of Listed Companies. Journal of Industrial Engineering and Engineering Management, 2019, 33(03): 24-34.

[20] Gamba, A., and A. J. Triantis. The value of financial flexibility[J]. Journal of Finance, 63 (5): 2263-2296

[21] Ma Chunai, Yi Cai. Research on the Influence of Manager Overconfidence on Financial Flexibility. Accounting Research, 2017(07): 75-81+97.

[22] Zhang Rongwu, Shen Qingyuan, Nie Huili. Economic Cycle, Investor Psychological Deviation and Asset Pricing. Accounting Research, 2011(07): 45-51.

[23] Shi Yanping, Liu Yuping. Nature of Property Rights, Risk Taking Advantage and Corporate Credit Spreads. East China Economic Management, 2019, 33(01): 119-128.

[24] Boubakri N,Cosset J C,Saffar W. The role of state and foreign owners in corporate risk-taking: Evidence from privatization. Journal of Financial Economics, 2013,108(3):641-658.

[25] Deng Kebin. How Banking Associations Alleviate Financing Constraints: Direct Mechanism or Indirect Mechanism. Contemporary Finance and Economics, 2017(05): 44-56.

[26] Song Peng, Tian Lili, Li Changhong. Cross-shareholding network and enterprise risk-taking. Economic Issues, 2019(06): 83-89.

[27] Wang Zhenshan, Shi Dalin. Institutional Investors, Financial Flexibility and Corporate Risk Taking: An Empirical Study Based on Dynamic Panel System GMM Model. Journal of Central University of Finance and Economics, 2014(09): 64-72.

[28] Zhang Jianqing, Qi Huaijin. Bank-enterprise linkages, financial flexibility and M\&amp;A: An analysis of empirical evidence from Chinese listed companies. Business Research, 2016 (07): 81-88. 


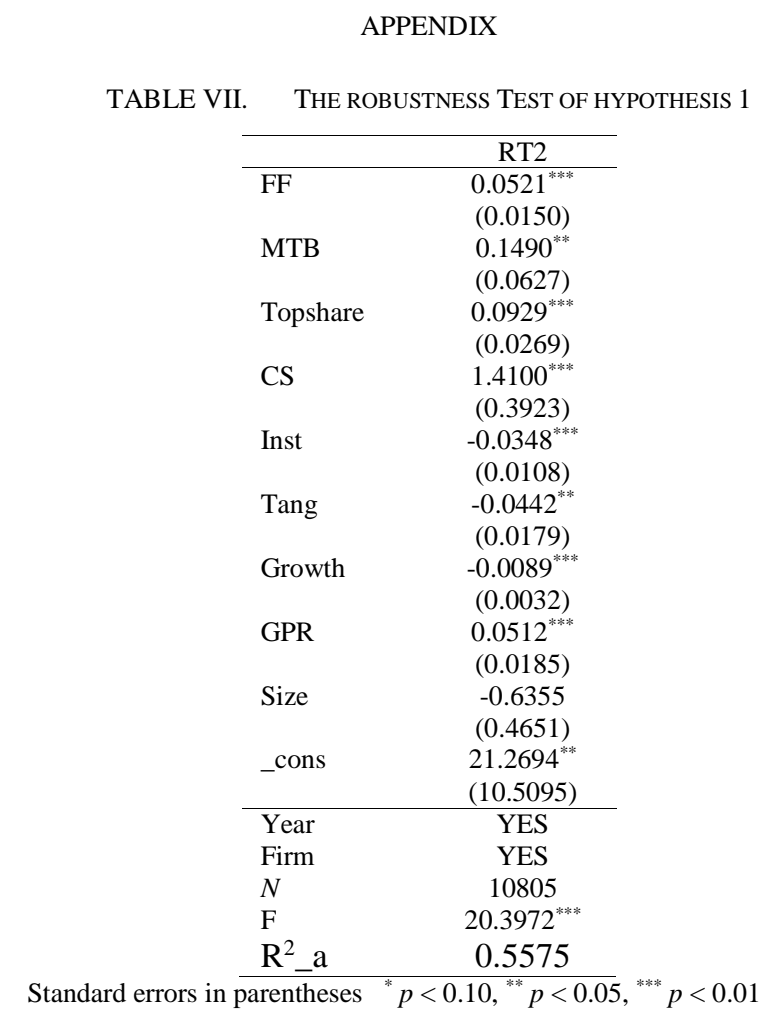

TABLE VIII. THE ROBUSTNESS TEST OF HYPOTHESIS 2

\begin{tabular}{|c|c|c|}
\hline & (1) & (2) \\
\hline FF & $\begin{array}{c}0.0503^{* * *} \\
(0.0151)\end{array}$ & $\begin{array}{l}0.0768^{* * * *} \\
(0.0214)\end{array}$ \\
\hline $\mathrm{AC}$ & $0.0779^{* * * *}$ & $0.1109^{* * * *}$ \\
\hline $\mathrm{AC} \times \mathrm{FF}$ & & $\begin{array}{l}(0.0298) \\
-0.0020^{*} \\
(0.0012)\end{array}$ \\
\hline МТВ & $\begin{array}{l}0.1330^{* *} \\
(0.0611)\end{array}$ & $\begin{array}{l}0.1309^{* *} \\
(0.0609)\end{array}$ \\
\hline Topshare & $\begin{array}{l}0.0941^{* * *} \\
(0.0269)\end{array}$ & $\begin{array}{c}0.0945^{* * * *} \\
(0.0269)\end{array}$ \\
\hline $\mathrm{CS}$ & $\begin{array}{l}1.4281^{* * *} \\
(0.3936)\end{array}$ & $\begin{array}{l}1.4312^{* * *} \\
(0.3923)\end{array}$ \\
\hline Inst & $\begin{array}{c}-0.0344^{* * * *} \\
(0.0108)\end{array}$ & $\begin{array}{c}-0.0341^{* * *} \\
(0.0108)\end{array}$ \\
\hline Tang & $\begin{array}{c}-0.0441^{* *} \\
(0.0180)\end{array}$ & $\begin{array}{c}-0.0435^{* *} \\
(0.0180)\end{array}$ \\
\hline Growth & $\begin{array}{c}-0.0086^{* * * *} \\
(0.0032)\end{array}$ & $\begin{array}{c}-0.0090^{* * *} \\
(0.0032)\end{array}$ \\
\hline GPR & $\begin{array}{l}0.0466^{* *} \\
(0.0189)\end{array}$ & $\begin{array}{l}0.0474^{* *} \\
(0.0189)\end{array}$ \\
\hline Size & $\begin{array}{l}-0.4901 \\
(0.4671)\end{array}$ & $\begin{array}{l}-0.4641 \\
(0.4667)\end{array}$ \\
\hline _cons & $\begin{array}{c}0.0503^{* * *} \\
(0.0151)\end{array}$ & $\begin{array}{c}0.0768^{* * * *} \\
(0.0214)\end{array}$ \\
\hline Year & YES & YES \\
\hline Firm & YES & YES \\
\hline$N$ & 10805 & 10805 \\
\hline $\mathrm{F}$ & $20.3972^{* * *}$ & $18.7431^{* * * *}$ \\
\hline $\mathrm{R}^{2} \mathrm{a}$ & 0.5575 & 0.5592 \\
\hline
\end{tabular}

TABLE IX. THE ROBUSTNESS TEST OF HYPOTHESIS 3

\begin{tabular}{ccc}
\hline & SOE $=1$ & SOE $=0$ \\
\hline FF & 0.0291 & $0.0656^{* * *}$ \\
MTB & $(0.0240)$ & $(0.0184)$ \\
& $0.1938^{* *}$ & $0.1839^{* *}$ \\
Topshare & $(0.0967)$ & $(0.0819)$ \\
& $\left(0.0355^{* * *}\right.$ & $0.1218^{* * *}$ \\
CS & $1.4949^{* *}$ & $(0.0410)$ \\
& $(0.5898)$ & $\left(0.4117^{* * *}\right.$ \\
Inst & $-0.0415^{* *}$ & $-0.0328^{* *}$ \\
& $(0.0173)$ & $(0.0137)$ \\
Tang & -0.0367 & $-0.0505^{*}$ \\
& $(0.0231)$ & $(0.0264)$ \\
Growth & -0.0020 & $-0.0091^{* *}$ \\
& $(0.0061)$ & $(0.0037)$ \\
GPR & $0.0640^{* * * *}$ & $0.0448^{*}$ \\
& $(0.0213)$ & $(0.0259)$ \\
Size & $-1.3675^{* *}$ & -0.2823 \\
& $(0.6093)$ & $(0.6391)$ \\
cons & $38.4730^{* * *}$ & 12.1565 \\
& $(13.3995)$ & $(14.4618)$ \\
\hline Year & YES & YES \\
Firm & YES & YES \\
$N$ & 4370 & 6435 \\
F & $7.5760^{* * * *}$ & $16.2991^{* * *}$ \\
R ${ }^{2}$ a & 0.6117 & 0.5305 \\
\hline Standard errors in parentheses & $p<0.10,{ }^{* *} p<0.05,{ }^{* * * *} p<0.01$
\end{tabular}

